\title{
腰椎椎間関節囊腫に対する内視鏡下摘出術の経験
}

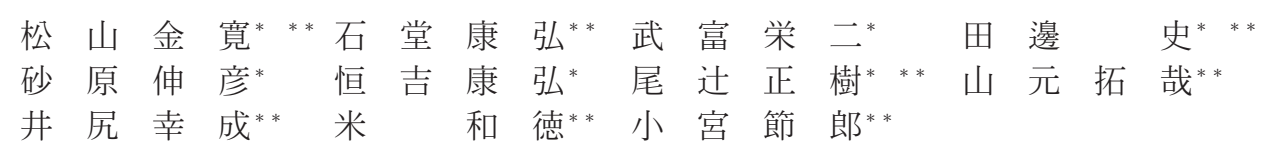

\section{Microendoscopic Resection for Lumber Facet Cyst : A Case Report}

\author{
Kanehiro Matsuyama***, Yasuhiro Ishido**, Eiji Taketomi*, \\ Fumito Tanabe***, Nobuhiko Sunahara*, Yasuhiro Tsuneyoshi*, \\ Masaki Otsuji***, Takuya Yamamoto**, Kosei Ijiri**, \\ Kazunori Yone**, and Setsuro Komiya**
}

今回，我々は脊柱管内に発生した椎間関節囊腫を内視鏡下に切除した。術中，合併症も無く安全に摘出 可能であった。術後, 不安定性の出現は無いが, 反対側に新たな囊腫の出現を認めた。術前より椎間関節 の変性がありあともと囊腫を形成しやすい病態が存在していたと考えられる.

A lumber facet cyst in the spinal canal was surgically treated with microendoscopy. No complication was found during or after the operation. No postoperative instability was observed, but a new cyst appeared in the opposite side. The degeneration of facet is thought to be the primary reason for cyst formation.

Key words : facet cyst (椎間関節囊腫), microendoscopy (内視鏡), less invasive surgery（低侵襲手術)

\section{はじめに}

脊柱管内囊腫性病変は MRI の普及に伴い診断も比 較的容易となり, 近年椎間関節囊腫屯散見されるよう になった、治療法としては，まずは保存的療法が原則 だが難治性のものに対しては椎弓切除術, 椎間開空術 といった観血的療法が行われている，その中で内視鏡 を応用し良好な成績を得たという報告むあり ${ }^{5)}$ ，今回 我々も内視鏡下に椎間関節囊腫を摘出した一例を経験 したので報告する。

\section{症例}

【症例】 67 歳, 男性

主訴：左下肢痛，歩行困難

既往歴: 平成 6 年 頚椎後縦勒带骨化症に対し椎弓形 成術
現病歴：平成 18 年 10 月, 右下肢痛が出現し近医を受 診した.MRI で腰部脊柱管狭窄症と診断され，当科 紹介受診となり右 L 5 の選択的神経根ブロックにて疼 痛消失し，以後保存的に経過観察していた。平成 19 年 6 月, 左下肢痛出現したため左 L 5 選択的神経根ブ ロックを施行し疼痛消失したが, 数日後に症状再増悪 した．MRIで再検したところ，L4/5からL5にかけ て腫瘤様病変を認めたため精査加療目的に当科入院と なった。

理学所見：SLR test が左で陽性であり，両側アキレ 又腱反射が消失していた，MMT は左で足関節の背屈 曲が (2), 母趾の背屈が（2）と低下が認められた. 知覚は, 左 L5, S 1 領域で $5 / 10$ の知覚低下が認めら れた。また，膀胱直腸障害も認めていた。JOA スコ アは $7 / 29$ 点 $(2-2-6-3)$ であった。

画像所見：単純レントゲンでは $\mathrm{L} 4 / 5$ 椎間関節の変性

鹿児島脊椎脊䯣研究班

* 鹿児島赤十字病院整形外科 Department of Orthopaedic Surgery, Kagoshima Red Cross Hospital, Kagoshima, Japan

** 鹿児島大学大学院運動機能修復学講座整形外科学 Department of Orthopaedic Surgery, Graduate School of Medical and Dental Sciences, Kagoshima University, Kagoshima, Japan 

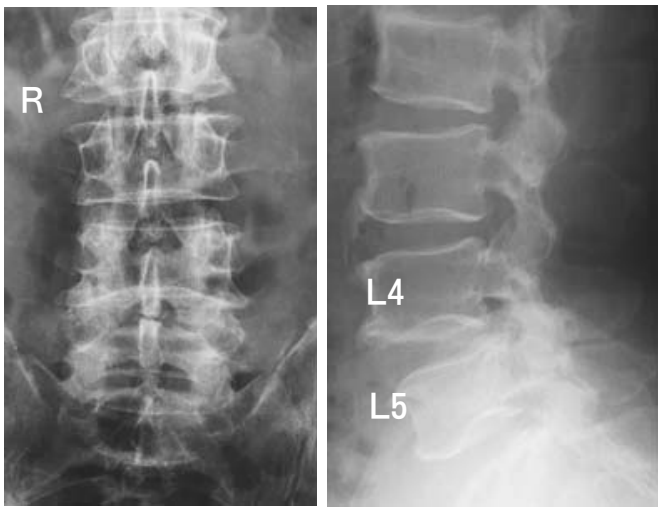

図 1 単純 X 線像

L4/5 椎間関節の変性, L4 の $2 \mathrm{~mm}$ の 前方すべりを認めた。

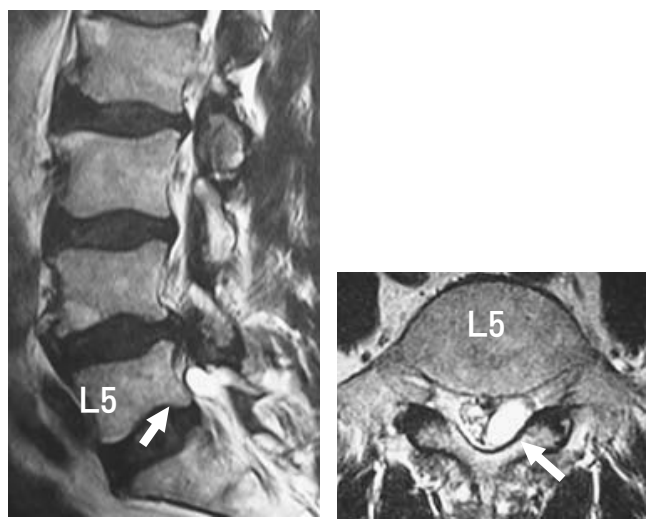

図 2 MRI (T2 強彫像)

L5レベルの脊柱管内左側に高輝度を 示す囊腫様病变 (矢印).

と， L 4 に $2 \mathrm{~mm}$ の前方すべりを認めるが，明らか な不安定性は認められなかった（図 1).MRI では, L5 レベルの脊柱管内左側に T2 強調像で高輝度を示 す囊腫様病変が認められた（図 2 ). 椎間板造影では, 囊腫内に造影剤の流出は認められなかった（図 3 ). 椎間関節造影では，左 L $4 / 5$ 椎間関節より囊腫内に造 影剂の流出が認められた（図 4 ）ため，椎間関節囊腫 と診断した。

手術 : 内視鏡下に左側 L $4 / 5$ の片側開空を行い，囊腫 を確認し被膜と一塊に摘出した（図 5 )。串腫の関節 滑膜との連続性は確認できたが，関節包との確認はで きなかった。また，黄色䩲帯との連続性は認められな かった。摘出標本は肉眼的にも囊腫を呈しており, 内

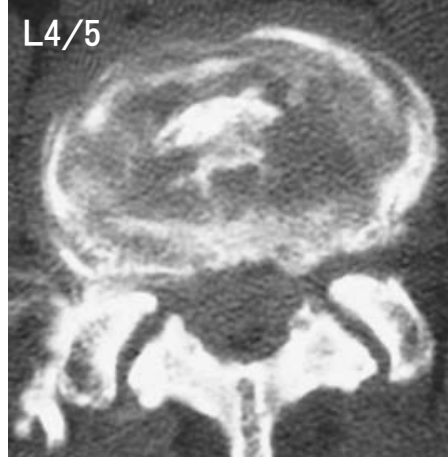

図 3 椎間板造影

囊腫内に造影剤の流出を認めない.

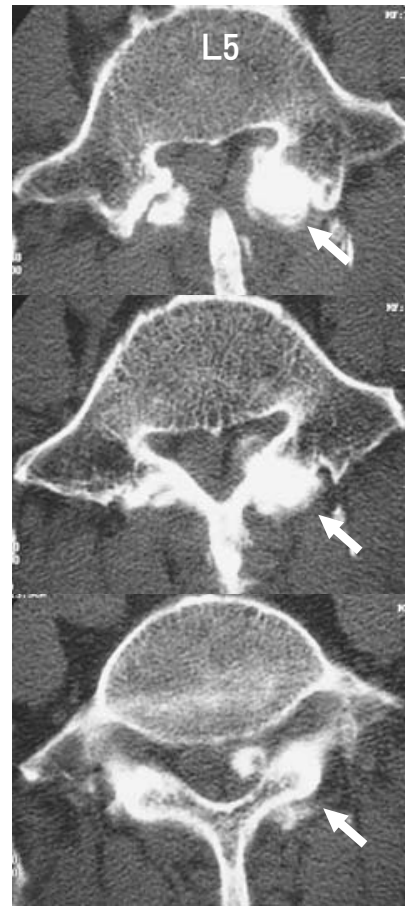

頭側

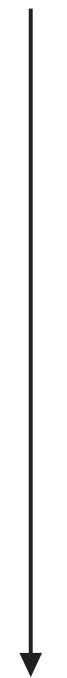

尾側

図 4 椎間関節造影

左 L $4 / 5$ 椎間関節より囊腫内に造影 剤の流出を認める (矢印).

部に黄色粘稠液が貯留していた。

病理組織学的所見：囊腫壁は細胞密度の低い線維組織 からなっており, 内部の粘液内には泡沫状組織球が散 在性に認められた。また，内腔面に明らかな lining cell は認められず, ganglion cystの診断であった。 


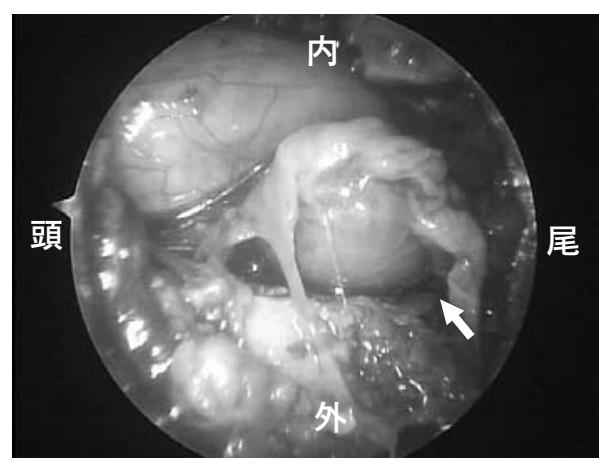

図 5 術中所見

内視鏡視下に左側 L4/5 の片側開空及び 囊腫摘出術を行った (矢印は囊腫を示す).
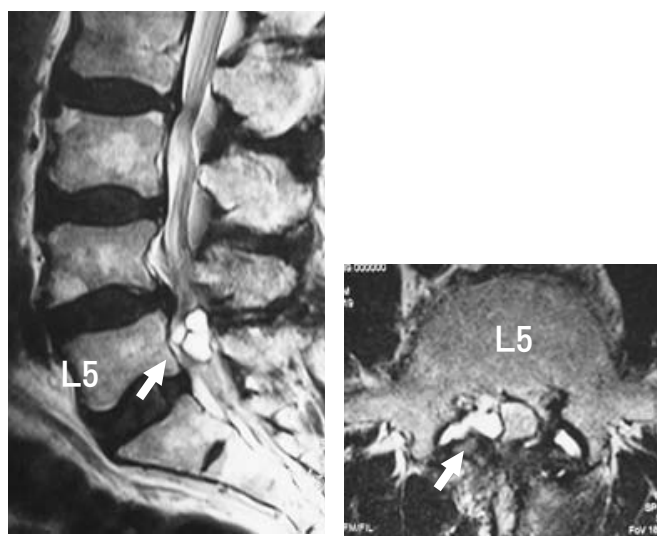

図 6 MRI (T2 強彫像) (術後 5 ヶ月) L5 レベルの春柱管内右側に新たな囊 腫様病変を認める (矢印).

術後経過：術後は合併症なく疼痛はほぼ消失しており， 現在術後 5 ヶ月でリハビリ中であり, JOA スコアは $7 / 29$ 点から 12/29点 (4-2-9-3) に改善した。し かし, 術後 5 ヶ月の MRIにて術前には認められなかっ た対側右側に囊腫様病変が認められた（図 6 )。軽度 の右下肢の痺れを認めるが，疼痛の訴えはなく現在経 過観察中である.

考察

椎間関節近傍に発生する囊腫性病変は病理組織学的 に synovial lining cell の有無と, 関節腔との交通性 の有無により synovial cyst と ganglion cyst に区別 されて報告されてきたが，Hsu ら ${ }^{2)}$ は同一震腫に両
者の組織所見を認めた症例を報告し，椎間関節囊腫 (facet cyst) と称することを提唱している。椎間関 節囊腫の発生，進展機序についてはいまだ一定の見解 はないが，椎間関節の関節症性変化を基盤とした椎間 不安定性による何らかの椎間関節包の破綻から襄腫壁 が形成されるとする説が一般的である。また，日下部 ら) は椎間関節造影にて椎間関節之囊腫の交通性を認 めたものを椎間関節囊腫と定義し，椎間関節の関節包 や黄色勒帯関節包部が破綻し亀裂が生じて囊腫が発生 すると推察している.

画像診断は MRI が最も有用であるが，椎間関節造 影や椎間板造影により椎間板囊腫や他の腫瘍と鑑別が 重要である.

治療に関しては，自然経過で縮小，消失する襄腫む あることから，椎間関節造影時の局所麻酔剂とステロ イドの注入，神経根ブロックなどの保存的療法が原則 であると考える。前回の我々の報告 ${ }^{1)}$ では 6 例中 4 例 が保存的療法により軽快している。しかし，伊藤ら ${ }^{3)}$ によると椎間関節造影を行い効果が持続して手術に至 らなかったのは 7 例中 1 例のみと報告されており,こ れらの経過には椎間関節の関節症变化の程度や不安定 性が影響していると考えられる。このように難治性の 場合は椎弓切除術, 椎間開空術, 椎弓形成術, 春椎徐 圧固定術といった観血的療法も選択され，最近では， 内視鏡を用いて襄腫を切除した報告あある。三浦ら ${ }^{5)}$ によると，囊腫発生椎間にすべりを伴った例に対して あ内視鏡下に囊腫を切除し，良好な成績が得られたと 報告されており，後方要素を温存でき，術後不安定性 をきたさないように囊腫を切除できる有効な手段の 1 つであると報告されている。今回我々も内視鏡を用い て, 術中術後の合併症もなく囊腫を摘出する事ができ, 椎間関節囊腫の治療に対し有用な術式の一つであった。

また，今回の症例においては術後 5 ヶ月の MRIに て反対側右側に新たな囊腫の出現を認めた。術後の不 安定性増強については，画像上は明らかではなかった。 しかし, 術前より反対側の椎間関節にも椎間関節の変 性があり, MRIであ関節水腫が認められており, 囊 腫が生じ易い病態があともと存在していたと考えられ る。現在，疼痛の訴えむなく経過観察中だが，椎間関 節囊腫に対して椎間開空術を行い半対側に再発を認め, 固定術を追加したとの報告ああり ${ }^{3)}$ ，今後症状増悪す る際には脊椎徐圧固定術を検討している。 
結語

椎間関節囊腫に対して内視鏡下での囊腫摘出術は有 用な術式の 1 つであった。

\section{参 考 文 献}

1）廣田仁志ほか：脊柱管内椎間関節囊腫の治療経験. 整 外之災外, 55(1) : 25-27, 2006.

2) Hsu, K. Y., et al. : Lumbar intraspinal synovial and ganglion cysts (facet cysts) ; ten-year experience in evaluation and treatment. Spine, $20: 80-89,1995$.

3）伊藤圭吾ほか：脊椎椎間関節脊柱管内囊腫の治療経験.

J. Tohkai Spinal Surg., 18: 58-60, 2004.

4）日下部隆ほか：腰椎椎間関節と交通する椎間関節近傍 囊腫（椎間関節囊腫）一病理組織像における検討一. 整 形・災害外科, $46: 1601-1609,2003$.

5）三浦一人ほか：内視鏡下に切除した腰椎椎間関節囊腫 の経験. 臨整外, 42:177-181, 2007. 